\title{
Do culverts impact the movements of the endangered white-clawed crayfish?
}

\author{
V. Louca ${ }^{(1), *, \star \star}$, H.M. Ream ${ }^{(1)}$, J.D. Findlay ${ }^{(1)}$, D. Latham ${ }^{(2)}$, M.C. Lucas ${ }^{(1)}$
}

Received June 12, 2014

Revised September 15, 2014

Accepted September 16, 2014

\begin{abstract}
Key-words: $\quad$ Culverts can impact the migration and dispersal of aquatic animals and crayfish, dispersal, tracking, result in population fragmentation, increasing the risk of local extinction for endangered species such as the white-clawed crayfish Austropotamobius pallipes. This study used radio telemetry and passive integrated Austropotamobius transponder (PIT) telemetry to determine whether existing and experimenpallipes, impoundment tal covered culverts affect the upstream and downstream movements of adult white-clawed crayfish. Daily crayfish movement rates did not differ significantly between an unlit 363-m long culvert and open stream channel sections. Crayfish moved into dark, covered sections volitionally. However, limited upstream movement occurred at sudden transitions of bed height or smooth-concrete box culvert sections with fast flow, suggesting partial barrier effects. In the 20-m long experimental in-stream culvert, also dark, but with natural stream bed, $70 \%$ of radio-tagged crayfish released downstream entered the culvert, as did $60 \%$ of those released upstream. Overall $35 \%$ passed through, with similar numbers in each direction. We conclude that dark culverts up to several hundred metres do not inhibit dispersal of white-clawed crayfish, provided stream slope, bed type and water velocity are amenable for movement and refuge. Care is required to ensure that culverts are bioengineered to ensure that average water velocity is sufficiently low and local hydraulic variation high, the bed and/or sidewalls contain refuge structures, and there are no cross-channel steps in bed level. Smooth-bedded box culverts are unlikely to be suitable for white-clawed crayfish.
\end{abstract}

\section{RÉSUMÉ}

Les ponceaux influent-ils sur les mouvements de l'écrevisse à pattes blanches en voie de disparition?

Mots-clés : écrevisse, dispersion, suivi télémétrique,
Les petits ponts d'une seule travée peuvent influer sur la migration et la dispersion des animaux aquatiques et entraîner la fragmentation de la population, augmentant le risque d'extinction locale des espèces menacées telles que l'écrevisse à pattes blanches, Austropotamobius pallipes. Cette étude a utilisé la télémétrie radio et la télémétrie par transpondeur passif intégré (PIT) afin de déterminer si les ponceaux couverts existants et expérimentaux affectent les mouvements en

(1) School of Biological and Biomedical Sciences, Durham University, UK

(2) CH2M HILL, Teesdale Business Park, Stockton-on-Tees, UK

* Present address: School of Biological Sciences, University of Aberdeen, Cruickshank Building, Aberdeen AB24 3UU, UK

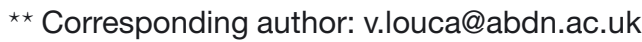


Austropotamobius amont et en aval de l'écrevisse à pattes blanches adulte. La vitesse de déplacepallipes, ponceau

ment des écrevisses ne diffère pas significativement entre un long ponceau fermé de $363 \mathrm{~m}$ et des sections de canaux ouverts. Les écrevisses se déplacent de leur propre gré dans les zones sombres couvertes. Cependant, un mouvement réduit vers l'amont intervient au niveau des transitions soudaines de la hauteur du lit ou des sections en béton lisse avec un débit rapide, ce qui suggère des effets de barrières partielles. Dans le ponceau expérimental de $20 \mathrm{~m}$ de long, également sombre, mais avec un lit de cours d'eau naturel, $70 \%$ des écrevisses radiomarquées relâchées en aval du ponceau est entré, de même que $60 \%$ de celles qui sont libérées en amont. Globalement $35 \%$ passe à travers, avec des chiffres similaires dans chaque direction. Nous concluons que les ponceaux sombres jusqu'à plusieurs centaines de mètres n'entravent pas la dispersion des écrevisses à pattes blanches, à condition que la pente du cours d'eau, le type de lit et la vitesse de l'eau se prêtent pour le mouvement et le refuge. Il faut veiller à ce que les ponceaux soient issus du génie biologique pour s'assurer que la vitesse moyenne de l'eau est suffisamment faible et que les variations locales hydrauliques importantes, que le lit et/ou des parois latérales contiennent des structures de refuge, et qu'il n'y a aucune rupture transversale au niveau du lit. Les ponceaux en béton lisse à profil rectangulaire sont peu susceptibles d'être adaptés à l'écrevisse à pattes blanches.

\section{INTRODUCTION}

Habitat fragmentation within freshwater systems in the form of dams, weirs and culverts is a major driver behind the fragmentation and decline of populations of aquatic species as they restrict access to important habitats for feeding, reproduction and predator avoidance and dispersal within and between populations (Dynesius and Nilsson, 1994; Richter et al., 1997; Gil-Sánchez and Alba-Tercedor, 2006). Lack of access to these habitats can ultimately lead to a reduction in recruitment, population decline, and a loss of biodiversity. Even though large-scale barriers such as hydroelectric dams receive significant research interest as to their impact on the movement of aquatic animals (Adams and Hughes, 1986; Richter et al., 1997; Benstead et al., 1999), it is often the case that in many catchments, smaller-scale obstructions such as weirs and culverts are the most frequent artificial barriers and thus may potentially have a greater overall impact (Katopodis, 2005; Franklin and Bartels, 2012).

The use of culverts for stream crossings, or as flood-control structures, is widespread, with the majority of studies focusing almost exclusively on the impacts of these structures on the movement of fish (Richter et al., 1997; Kemp and Williams, 2009; Tonkin et al., 2012), with little consideration of other aquatic species. Nevertheless, these structures can have significant impacts on non-fish species (Richter et al., 1997; Acosta and Perry, 2001; Blakely et al., 2006; Jones and Bergey, 2007; Foster and Keller, 2011). Connectivity of crayfish populations within rivers is probably achieved through a combination of downstream drift of very young juveniles, together with active upstream and downstream movement by larger juveniles and adults (Robinson et al., 2000). Therefore, structures that may act as barriers to movement through alteration of habitat or by creating physically impassable barriers are expected to contribute to the fragmentation of populations. The majority of studies that relate crayfish distribution and movement to river impoundments such as culverts have focused primarily on the potential of culverts and weirs to limit the geographical spread of introduced species of crayfish (Light, 2003; Kerby et al., 2005; Dana et al., 2011; Foster and Keller, 2011; Frings et al., 2013; Maceda-Veiga et al., 2013), thus further highlighting the potential ability of these structures to negatively impact native species of crayfish.

Culverts can restrict movement and limit dispersal of crayfish, as well as other aquatic animals by causing the elevation of water velocity, increasing channel homogeneity and alteration of river bed structure, or creating direct barriers through the positioning of elevated culvert outlets and mini weirs (Bubb et al., 2008; Souty-Grosset and Reynolds, 2009; Franklin and Bartels, 2012). More specifically, it has been shown that crayfish dispersal is closely linked 
to water flow patterns (Acosta and Perry, 2001), and that water velocities as low as $2 \mathrm{~cm} \cdot \mathrm{s}^{-1}$ can impede upstream movement of native North American crayfish Orconectes propinquus (Girard, 1852), and O. virilis (Hagen, 1870) (Foster and Keller, 2011), but at the same time velocities up to $10 \mathrm{~cm} \cdot \mathrm{s}^{-1}$ have no impact on the upstream movement of Procambarus clarkii (Girard, 1852), a highly invasive species (Kerby et al., 2005).

Culverts are often covered structures and, in such cases, a frequently overlooked factor potentially limiting the free movement of native crayfish is the alteration of the light regime, creating a permanently dark environment through which animals have to pass to access adjacent habitats. This could potentially alter the behaviour and movement patterns in crayfish and act as a behavioural barrier to dispersal. It has been shown that crayfish behaviour is influenced by changes in light intensity (Fanjul-Moles and Prieto-Sagredo, 2003; Fanjul-Moles et al., 2004), and even species that live in dark caves exhibit circadian entrainment (Jegla and Poulson, 1968). Studies on potential behavioural obstacles as a result of dark culverts have, so far, unsurprisingly, focused on fish. It has been shown for example, that the ability of Pacific salmon Oncorhynchus spp. smolts to negotiate obstacles such as weirs and culverts decreases during low-light conditions (Kemp and Williams, 2009). Other studies have shown that some migratory fish species may either delay entering darkened culverts, or avoid entering them completely (Larinier, 2002).

Published information on the impact of dark culverts on crayfish movement and dispersal remains scarce. Taking into account the ecological status and importance for conservation of the endangered white-clawed crayfish Austropotamobius pallipes (Lereboullet, 1858) (Holdich et al., 2009; Peay and Füreder, 2011; IUCN 2013), it is important to better understand how this particular species of crayfish responds to such structures in order to minimise impacts of existing and new culverts. It is documented that crustaceans and especially crayfish species are often attracted out of their hiding places by dim light but they demonstrate withdrawal at high light intensities (Fernandez-De-Miguel and Arechika, 1992). The majority of crayfish species tend to be attracted to burrows and hide under pebbles and cobbles, possibly as an antipredatory mechanism as well as a way of avoiding being swept downstream by high water flows (Alberstadt et al., 1995). Furthermore, crayfish being primarily nocturnal, do exhibit significantly higher rates of locomotor activity during low-light conditions at night-time (Bojsen et al., 1998). It is, therefore, hypothesised that the dark conditions created by culverts, will not restrict crayfish movement through culverts, provided other environmental factors such as water flow and river bed structure remain amenable to movement.

\section{MATERIALS AND METHODS}

\section{> EXPERIMENTAL RATIONALE}

This study used a combination of an existing covered culvert and an experimental dark culvert, built from scaffold and formwork panels, set within a natural river channel to determine their effects on the willingness of adult white-clawed crayfish to pass through the culverts in either direction, and on the pattern of day-to-day movements, determined by radio telemetry and passive integrated transponder (PIT) telemetry. These experiments were carried out in summer, when crayfish of both sexes are active (Bubb et al., 2008). Specifically the aim was to determine the frequency, rates and direction of entry and traversal through the culvert types and to compare spatial behaviour within culverts to control conditions outside. The study was licensed by Natural England.

\section{> STUDY SITE}

The study was carried out in the River Wansbeck catchment, Northeast England $\left(55^{\circ} 10^{\prime} \mathrm{N}\right.$, $1^{\circ} 41^{\prime} \mathrm{W}$ ). The Wansbeck is a gravel-bed river, almost $60 \mathrm{~km}$ long, with a catchment of $331 \mathrm{~km}^{2}$ and a width of about $25 \mathrm{~m}$ at the lower end. The upper $20 \mathrm{~km}$ of river catchment has an 


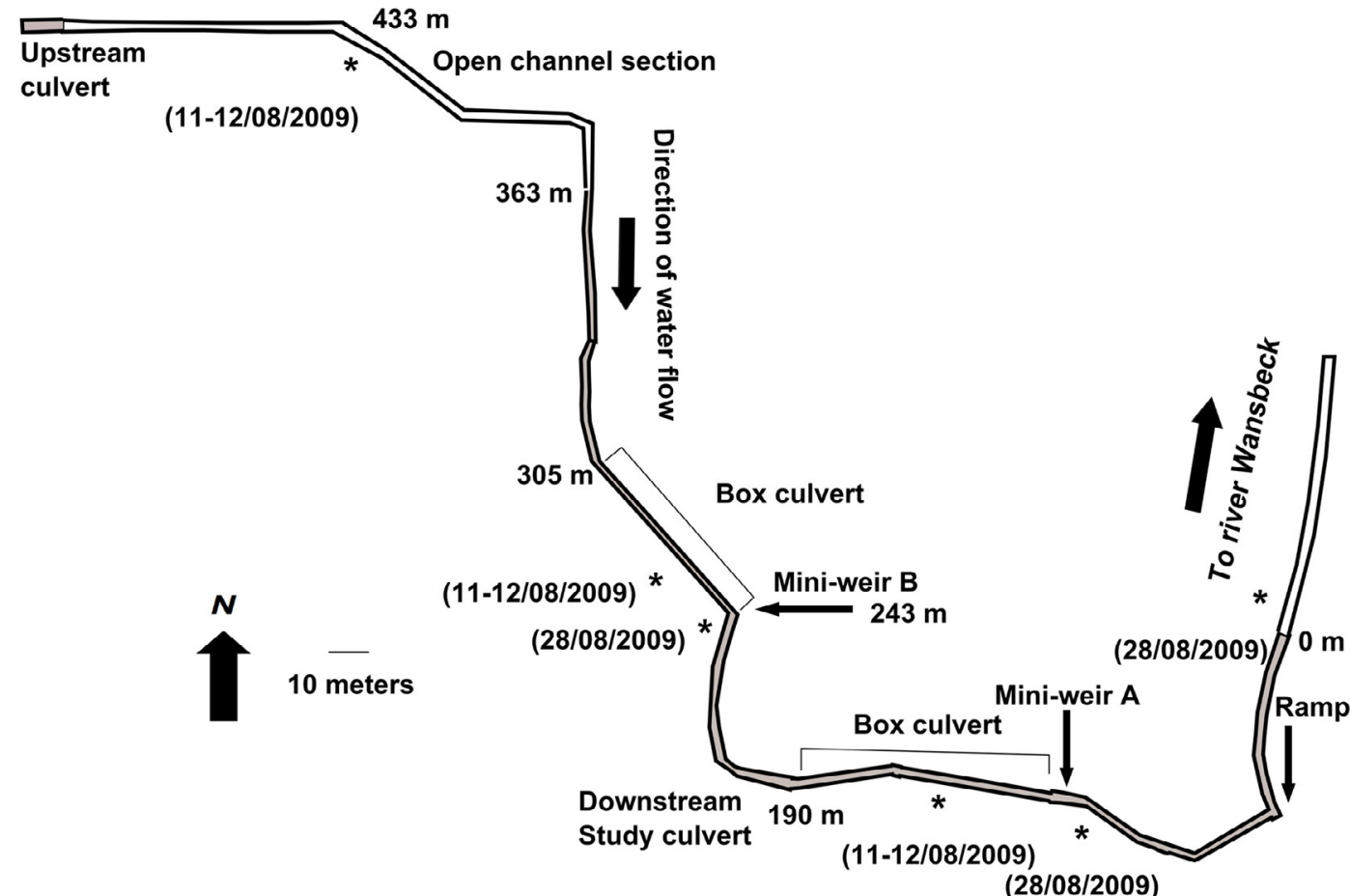

Figure 1

Schematic diagram showing the layout of the Cotting Burn covered culvert used in the study and the location and dates of crayfish releases. PIT-tagged and radio tagged crayfish were released at the same location, indicated by asterisks. Distances (chainage) indicated from the downstream entrance of the culvert.

underlying geology of carboniferous limestone. Most of the catchment is covered by glacial till, which is clayey and results in a flashy hydrograph. Water quality in the upper and middle catchment is consistently classified as "very good", both chemically and biologically, but in the lower reaches is more variable with high dissolved oxygen but also with high phosphorus levels. The land use is largely moorland in the upper reaches, mixed agriculture with a wide riparian buffer strip in the middle reaches and mixed agriculture with some urban development in the lower reaches, particularly at two towns, Morpeth and Ashington.

Two principal sites were employed in this study, one on the Cotting Burn $\left(55^{\circ} 10.05^{\prime} \mathrm{N}\right.$, $\left.1^{\circ} 41.20^{\prime} \mathrm{W}\right)$, a heavily modified and partially culverted stream running through Morpeth (Figure 1) meeting the Wansbeck about $43 \mathrm{~km}$ from its source, and an experimental culvert in the main Wansbeck channel upstream of Mitford $\left(55^{\circ} 9.7^{\prime} \mathrm{N}, 1^{\circ} 45.9^{\prime} \mathrm{W}\right)$, about $35 \mathrm{~km}$ downstream from the river's source.

\section{> COTTING BURN - CULVERT CHARACTERISTICS}

The existing culvert at Cotting Burn (Figure 1) included two unlit covered culvert sections, each several hundred metres in length, separated by a section of open channel of approximately $140 \mathrm{~m}$ long, and with another length of open channel downstream of the lower covered culvert, which empties into the Wansbeck, approximately $300 \mathrm{~m}$ downstream. The study section utilized the lower culvert, $363 \mathrm{~m}$ in length, and open stream channel either side (Figure 1). The culvert consisted of a mixture of natural stone slab and concrete box culvert, 2-3 $\mathrm{m}$ wide and 1-1.5 m high, without internal lighting (Table I) Along the length of the culvert, drainage pipes of a range of sizes emerged into the culvert, close to water level. The open-channel reaches either side of the covered culvert section comprised semi-natural stream habitat and incorporated abundant crayfish refuges and no vertical steps or steep gradients that might inhibit upstream movement. 


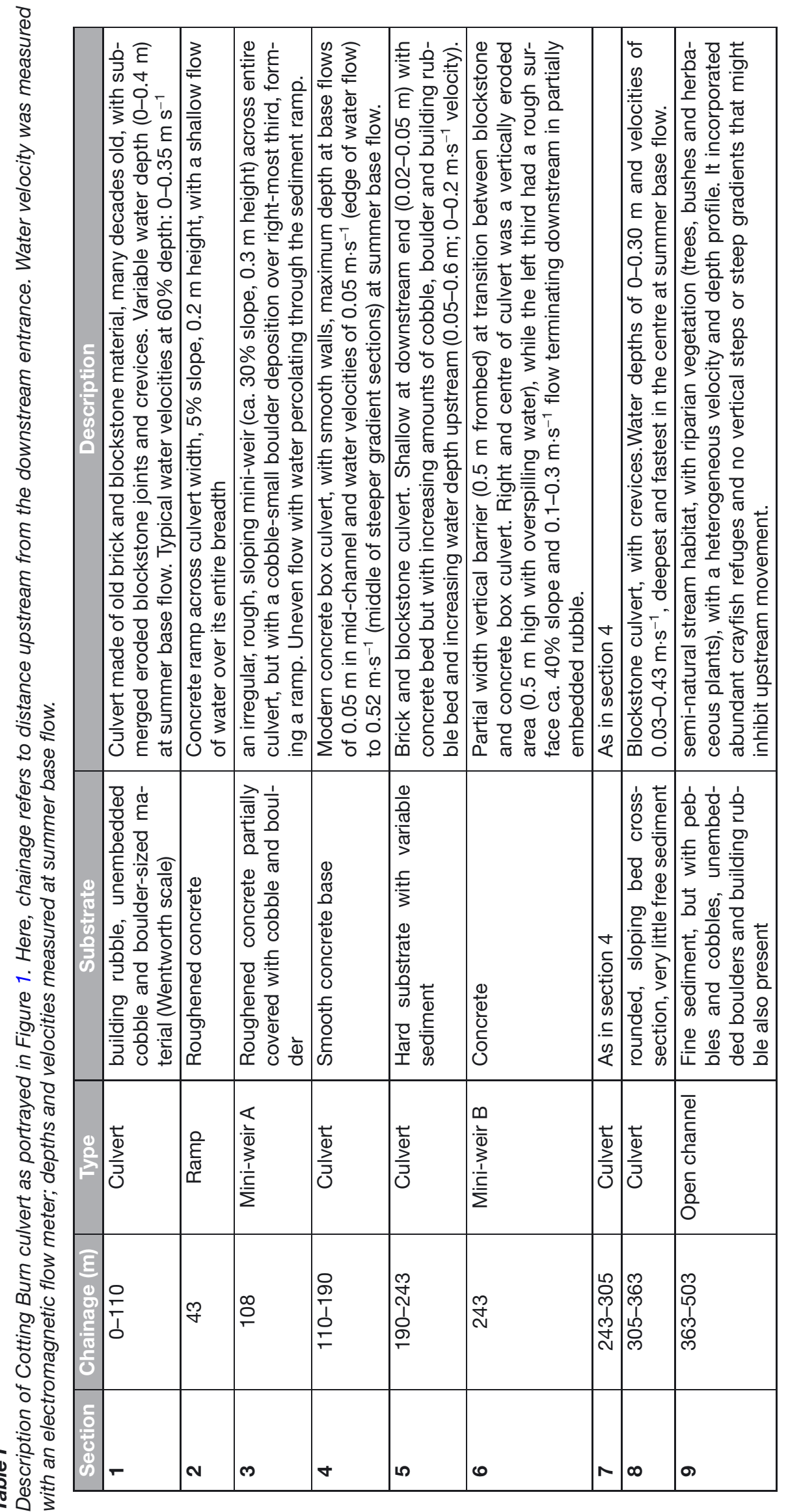


Several of the covered culvert zones described above, especially the concrete box culvert sections, represented potential barriers to crayfish upstream movement, having velocities mostly exceeding $0.3 \mathrm{~m} \cdot \mathrm{s}^{-1}$, a threshold value reported to limit upstream movement by crayfish (Kerby et al., 2005; Foster and Kelly, 2011), and/or a smooth concrete bed (Table I). However, in these locations crayfish could potentially, at low flow, walk in the shallowest edge flow or on the adjacent emerged region, in the humid culvert. Furthermore, other potential barriers to crayfish movement existed within the culvert (Table I). At the start of the study, S-shaped cross-section, clay pantiles $(350 \times 250 \mathrm{~mm})$ were placed obliquely to the flow every $5 \mathrm{~m}$ along the length of the culvert to provide refuges from flow and potential predators, particularly in the box culvert section.

\section{> COTTING BURN - CRAYFISH COLLECTION AND TAGGING}

Preliminary observations in spring 2009 showed that while the Cotting Burn contained whiteclawed crayfish, they were at too low a density to make collection for experiments using the resident population viable. For this reason crayfish were collected from the main channel of the Wansbeck $\left(55^{\circ} 9.7^{\prime} \mathrm{N}, 1^{\circ} 45.9^{\prime} \mathrm{W}\right)$, and released at the Cotting Burn site for experiments, under licence.

Crayfish were collected by hand-searching, measured, sexed and tagged before releasing. Radio tags (type PIP, Biotrack), $17 \times 9 \times 6 \mathrm{~mm}$, with a mass of $0.8 \mathrm{~g}$ were attached to the carapace of crayfish larger than $3 \mathrm{~mm}$ carapace length $(\mathrm{CL})$, using dental acrylic (Robinson et al., 2000; Bubb et al., 2006). Radio tags were distinguished by unique frequencies and had a life exceeding 1 month. In total 36 radio-tagged crayfish were released, 10 of which were females $(C L$ range $=30.3-38.1 \mathrm{~mm}$; mean $=34.4 \mathrm{~mm})$ and 26 were males $(C L$ range $=$ 32.7-47.4 mm; mean $=39.8 \mathrm{~mm}$ ). Sterile Passive Integrated Transponder tags (PIT tags), $12 \times 2 \mathrm{~mm}$, (Wyre Micro Design TAG-P-122GL), each with a unique code, were internally implanted in crayfish with a minimum $\mathrm{CL}$ of $24 \mathrm{~mm}$ following the methodology of Bubb et al. $(2002,2008)$. A total of 105 PIT-tagged crayfish were released in the Cotting Burn, of which, 50 were females $(C L$ range $=24.5-37.8 \mathrm{~mm}$; mean $=30.0 \mathrm{~mm})$ and 55 were males $(C L$ range $=$ 24.7-43.9 mm, mean $=31.0 \mathrm{~mm}$ ). Furthermore, tagged crayfish were batch tagged with a small external heat brand (2-mm diameter), identifying the release location, independent of telemetry tags.

Crayfish were independently released at Cotting Burn on two occasions, 11-12 August and 28 August 2009 (Figure 1). On each occasion crayfish were released at three different locations, one of which served as a control (released outside the culvert) with the other two released in the culvert (Figure 1). On the first release, five radio- and 35 PIT-tagged crayfish were released at each location. Control crayfish were released in the open channel midway between the culverts. The release locations within the culvert were chosen to provide the best opportunity for widespread movement in relation to existing likely impediments to movement mentioned above. One treatment group was released inside the culvert at $128 \mathrm{~m}$ from the downstream entrance and about $25 \mathrm{~m}$ upstream of mini-weir A (Figure 1). The second group was released $263 \mathrm{~m}$ from the downstream entrance and about $25 \mathrm{~m}$ upstream from mini-weir B (Figure 1). These release sites represent $35 \%$ and $72 \%$ respectively of the distance along the culvert from the downstream exit.

The second release comprised seven radio-tagged at each of three sites. Following evidence of likely crayfish predation by rats in the box culvert after the first release (see Results), the two culvert groups were released $10 \mathrm{~m}$ downstream of the mini-weirs ( $A$ and $B$ ) bordering the box culvert sections, $98 \mathrm{~m}$ and $233 \mathrm{~m}$, respectively from the downstream entrance of the culvert (Figure 1). These locations had large amounts of rubble, giving crayfish more protection from predators. The controls were placed $10 \mathrm{~m}$ below the downstream exit of the culvert to determine whether crayfish would move upstream and enter the culvert.

Following crayfish release, the entire study length of approximately $800 \mathrm{~m}$ was scanned six days per week, by day, for tagged crayfish, working in an upstream direction, using a VHF radio receiver (Sika, Biotrack) and pole-mounted PIT detector (modified Trovan LID500, Wyre 


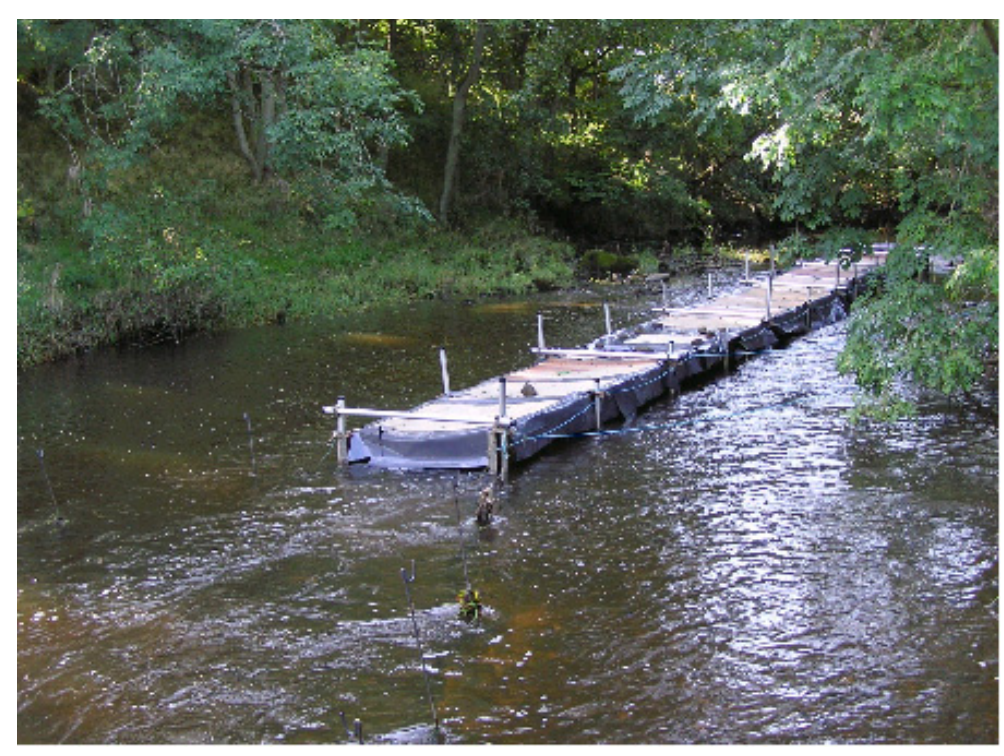

Figure 2

Photograph of the experimental culvert.

Microdesign, Bubb et al., 2002). Radio-tracking continued until 9 September 2009 and PIT telemetry continued until 30 August 2009 when an equipment fault prevented further PIT detection. Located crayfish were recorded within pre-marked 1-m stream sections. While the radio tags had ranges of at least several tens of metres (with a folded Yagi or monopole antenna) aiding effective location, PIT tag range was less than $0.2 \mathrm{~m}$ and depends on tag orientation, requiring scanning of the full channel width over the substrate (Bubb et al., 2002). This can have a low efficiency, especially where access into deep crevices or under boulders occurs. PIT telemetry was, therefore, used as a "mark-recapture" method rather than an individual tracking technique. Water quality (dissolved oxygen, conductivity, $\mathrm{pH}$, water temperature) was recorded prior to and throughout the study, immediately below the culvert using calibrated hand-held meters (VWR DO200, Hannah 98127). A light meter (Iso-Tech 1733, 0.01 Lux resolution) was used to measure the decrease in light intensity along the culvert by day.

\section{> EXPERIMENTAL CULVERT}

An experimental covered culvert was constructed in August 2009 in the River Wansbeck $\left(55^{\circ} 9.7^{\prime} \mathrm{N}, 1^{\circ} 45.9^{\prime} \mathrm{W}\right)$, with the aim of determining the passage of crayfish through it in natural bed habitat. At this site the river is $10-12 \mathrm{~m}$ wide and typically $0.1-0.6 \mathrm{~m}$ deep at base river flow, with a natural bed dominated by cobble, boulder and gravel. There is sparse instream vegetation but the banks are tree-lined and there is a dense white-clawed crayfish population (Ream, 2010; Pearson, 2011). The culvert (length: $20 \mathrm{~m}$, width: $1.2 \mathrm{~m}$, height: $0.8 \mathrm{~m}$ ) was constructed from modular formwork panels, supported by a scaffold framework (Figure 2). The culvert was aligned approximately with the flow and ran from the downstream end of a riffle into a glide, in water less than 0.6-m deep. To minimise any damage done to the crayfish, temporary $0.3-\mathrm{m}$ high $8-\mathrm{mm}$ mesh fences, embedded in the substrate, were placed in the river bed immediately upstream and downstream of the culvert site prior to the construction and the area was intensively hand searched with all crayfish removed and placed outside of the fences, on the side nearest to where they originated. The footprint edges where the culvert would be based were carefully cleared of stones. The side panels were placed on 0.3-m bases of pre-washed gravel in muslin bags to provide gap-free edges and minimize entry/exit of crayfish through the sides. The inside of the culvert was left unmodified and the bed comprised approximately $60 \%$ cobble, $25 \%$ boulder and $15 \%$ gravel at the bed's surface. 
The top of the culvert was covered with removable plywood lids, covered and overlapped by black, heavy duty plastic sheeting to mimic a built covered environment without internal lighting and to limit light entry to the two ends.

Following construction, the stream channel within approximately $50 \mathrm{~m}$ upstream and downstream of the culvert fences was searched for crayfish of a suitable size for PIT tagging (minimum of $24 \mathrm{~mm} \mathrm{CL}$ ). For each area, samples of crayfish with a minimum CL of $3 \mathrm{~mm}$ were radio-tagged as described previously. Of the 20 crayfish radio-tagged, eight were females $(\mathrm{CL}$ range $=32.7-37.1 \mathrm{~mm}$; mean $=34.6 \mathrm{~mm})$ and 12 were males $(\mathrm{CL}$ range $=34.6-42.6 \mathrm{~mm}$; mean $=37.4 \mathrm{~mm}$ ). Remaining crayfish were PIT tagged and batch marked in upstream or downstream capture-and-release groups. Of the PIT-tagged crayfish released outside the experimental culvert, 82 were females $(C L$ range $=24.1-35.1 \mathrm{~mm}$, mean $=29.12 \mathrm{~mm})$ and 97 were males $(C L$ range $=24.3-41.0 \mathrm{~mm}$, mean $=31.37 \mathrm{~mm}$ ). Ten radio-tagged and 86 PITtagged crayfish were released $5 \mathrm{~m}$ upstream of the culvert on 19 August 2009 and ten radiotagged and 93 PIT-tagged crayfish were released $5 \mathrm{~m}$ below the culvert on 20 August 2009. Immediately after release on 20 August 2009 the mesh barriers preventing crayfish access to the culvert during the construction period were removed and placed obliquely from the bank to the opening of the culvert at both ends to mimic the constraints a typical culvert generates on upstream/downstream movement, such that crayfish released downstream were free to move downstream, but to move upstream had to pass through the culvert and vice versa. The experiment ran from 20 August to 9 September 2009. The areas within and immediately around the culvert were scanned using a pole mounted PIT detector on seven occasions between 21 and 30 August and the location of each tagged crayfish identified ( $0.2 \mathrm{~m}$ precision). PIT scanning in the culvert each day (ca. 10:00 h) required the opening of the culvert cover for $<30$ mins, but was the only way the culvert could be scanned safely for PIT tags. Since crayfish were concealed at this time of day, and the substrate was not disturbed, it is expected that this had little disturbance on their behaviour. Prior tests had shown that this method can distinguish between tagged crayfish next to the inside or outside edge of the culvert. In addition to the scanning, the culvert area was intensively hand-searched for marked crayfish at the end of the experiment to complement telemetry. Radio-tagged crayfish were located, by day, to within $2 \mathrm{~m}$ precision, anywhere in the river, using bankside reference markers, and to within $1 \mathrm{~m}$ on the river's longitudinal axis in the culvert, six days per week, except when strongly elevated flow conditions prohibited safe entry in the river. Under high-flow conditions, approximate radio-locations, equal to or better than $5 \mathrm{~m}$ precision, were obtained. These radio tags had a detection range of about $100 \mathrm{~m}$ under field conditions, using a 3-element Yagi antenna. For radio-tagged crayfish detected along the culvert, use of a low-gain monopole radio antenna enabled confirmation of crayfish presence between, rather than outside the culvert walls.

The water velocity within and either side of the culvert was measured at $60 \%$ of depth, $1 \mathrm{~m}$ from each side and in the middle of the culvert. Light intensity along the culvert was also measured. River discharge data for the Wansbeck was obtained for the Mitford gauging site, $2 \mathrm{~km}$ downstream of the experimental culvert.

\section{RESULTS}

\section{> COTTING BURN CULVERT}

Light intensity in the Cotting Burn culvert declined from over 1000 Lux by day outside the culvert to 1 Lux within the first $2 \mathrm{~m}$ inside the entrance of culvert and subsequently ranged between $0.1-0.5$ Lux further in, except in the locality of surface grills where the light was elevated to 1 Lux. Stream flows were mainly low and stable for most of the study, but were markedly elevated on three occasions, following local rain, in the last week of August and first week of September 2009, causing an increase in turbidity. Dissolved oxygen exceeded $75 \%$ saturation from several weeks before the start of the study to the end, $\mathrm{pH}$ remained within the range 8.2 to 8.7 and water temperature was 12.5 to $16.0^{\circ} \mathrm{C}$. Conductivity was more variable 

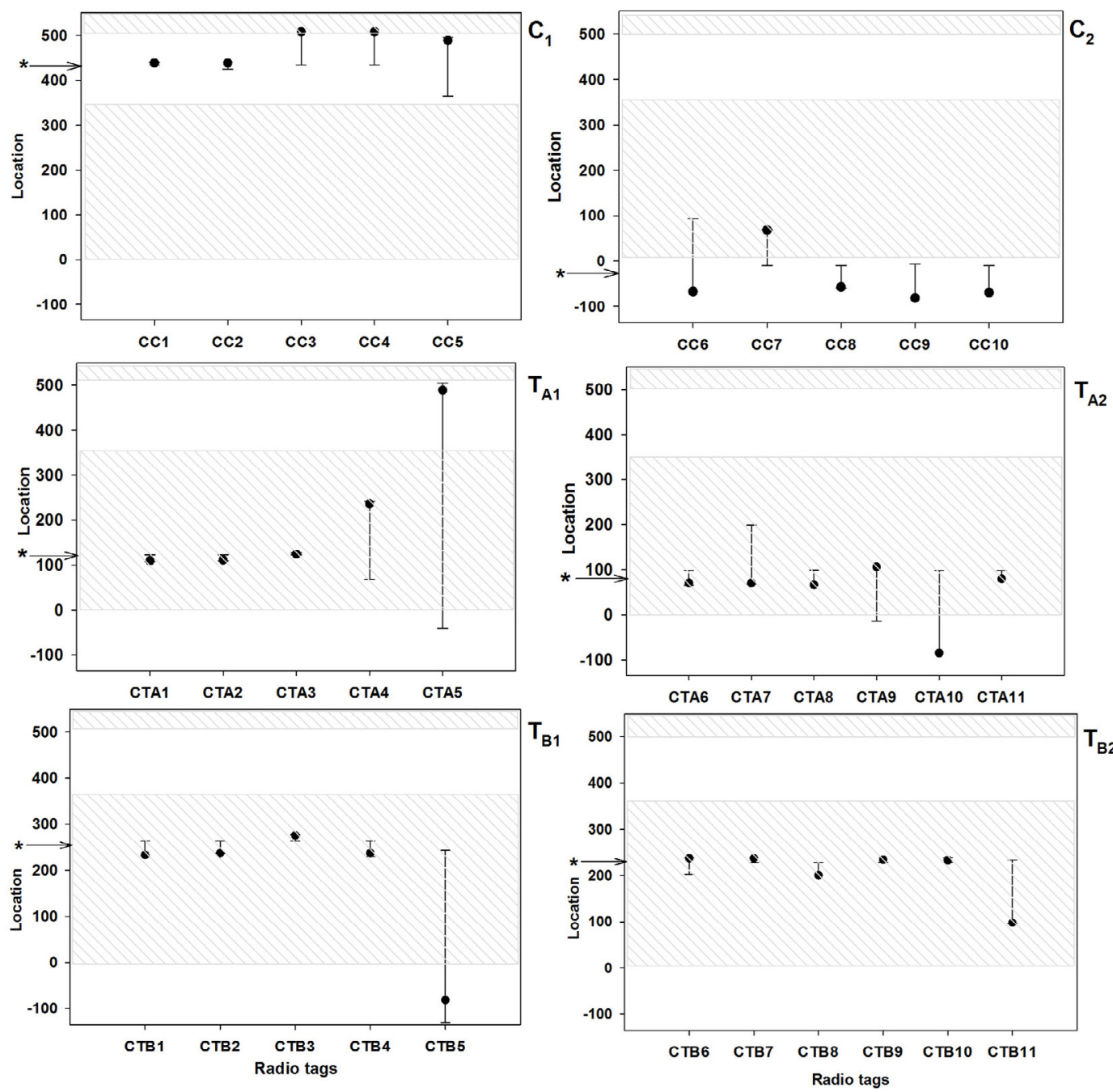

\section{Figure 3}

Movements of radio-tagged crayfish in the Cotting Burn. The hatched regions indicate the extent of covered culverts, although the upstream culvert continues further upstream than shown. For each crayfish the vertical line represents the maximum extent of movement in upstream and downstream directions from the release point, indicated by *, and the final position is indicated by a slid circle. Batch 1 released on 10 and 11 August 2009: $C_{1}$ : controls, released $70 \mathrm{~m}$ upstream of the culvert, $T A_{1}$ : released in the culvert $128 \mathrm{~m}$ from the downstream entrance, $T B_{1}$ : released in the culvert $263 \mathrm{~m}$ from the downstream entrance. Batch 2, released on 28 August 2009, $C_{2}$ : controls, released $10 \mathrm{~m}$ outside the downstream entrance of the culvert, $\mathrm{TA}_{2}$ : released in the culvert $98 \mathrm{~m}$ from the downstream entrance, $\mathrm{TB}_{2}$ : released in the culvert $233 \mathrm{~m}$ from the downstream entrance.

(510-905 $\left.\mu \mathrm{S} \cdot \mathrm{cm}^{-1}\right)$, with low values observed occurring at higher flows and reflecting solute dilution effects.

Two (of five) of the radio-tag control (open channel) crayfish from the first release moved upstream and were detected as being in the upstream culvert, although the exact location was not known (Figure 3). A similar situation was observed for the second group of control animals released $10 \mathrm{~m}$ downstream of the study culvert, in which two (of seven) crayfish moved upstream and into the study culvert to a distance of $100 \mathrm{~m}$; subsequently one of those two crayfish moved back out of the culvert.

For crayfish released in the lower part of the culvert on the first occasion, all crayfish stayed in the culvert with the exception of one which moved first downstream and outside the entrance of the culvert and subsequently moved through the culvert and all the way to the entrance of the upstream culvert (Figure 3). For the second group of crayfish released in the lower part 
of the culvert, one (of seven) crayfish moved downstream, outside the culvert and remained there, while another left the culvert, but re-entered it. A similar pattern was observed for the crayfish released at $263 \mathrm{~m}$ from the downstream culvert entrance where one crayfish moved downstream and outside the culvert (Figure 3). Small day-to-day shifts in location showed that most tagged crayfish remained alive, although tag signals from three crayfish were lost soon after release, or were located stationary due to tag loss or death of the crayfish. Two (of five) radio tags from the first culvert treatment groups and one tag (of seven) from the second culvert treatment groups were located in storm drains, separated vertically from the stream bed by over $10 \mathrm{~cm}$ and associated with crayfish fragments, partially eaten vegetable matter and rat faeces.

Of the 105 PIT-tagged crayfish released in the Cotting Burn, 79 (75\%) were detected at least once. Most PIT-tagged crayfish remained in the vicinity of the release site but some individuals moved substantial distances upstream and downstream (Figure 4), including several movements into and out of the culvert. No net directional tendency over time was observed for any of the three groups released (regression analyses, all $P>0.05$ ). The results suggest a limited movement upstream from release sites in concrete box culverts, indicated by the high frequency of crayfish detected immediately downstream of the release site and potential barriers (Figure 4). However, some crayfish did move upstream and the proportion of crayfish moving upstream was higher in the covered culvert than it was in the open channel section with more natural stream bed and banks (Figure 4). Two PIT tags from crayfish released in the culvert were located in storm drains, elevated above the water flow and associated with crayfish remains and rat faeces.

\section{> EXPERIMENTAL CULVERT}

The light levels within the experimental culvert dropped to 0.1 Lux within $5 \mathrm{~m}$ of the entrance, comparable to the levels measured in the Cotting Burn culvert and therefore to the light levels expected in an unlit culvert. Water velocity in the middle of the culvert varied substantially along its length (Mean: $0.47 \mathrm{~m} \cdot \mathrm{s}^{-1}$, Range: $0.31-0.61 \mathrm{~m} \cdot \mathrm{s}^{-1}$ ) according to the local hydraulics, but intermediate to the velocities recorded on each side (Left side Mean: $0.45 \mathrm{~m} \cdot \mathrm{s}^{-1}$, Range: $0.16-0.98 \mathrm{~m} \cdot \mathrm{s}^{-1}$; Right side mean: $0.54 \mathrm{~m} \cdot \mathrm{s}^{-1}$ Range: $0.14-0.89 \mathrm{~m} \cdot \mathrm{s}^{-1}$ ).

All radio-tagged crayfish were detected each day, until the end of the experimental period. Out of the ten crayfish released downstream of the culvert, seven moved upstream into the culvert and of those three passed through and outside the culvert. Six out of ten crayfish released upstream of the culvert moved downstream and into the culvert with four of those moving all the way through the culvert (Figure 5).

Crayfish daily movement was negatively related $\left(P<0.05, R^{2}=0.50\right)$ to river flow with the highest movement observed during low river flow conditions (Figure 6). Average daily movement of radio-tagged crayfish was not significantly different between the groups released upstream and downstream of the culvert (One-way ANOVA, $F=1.04, P=0.386$ ). Furthermore no significant differences were observed between the average daily movement (Table II) of radio-tagged crayfish released in the Cotting Burn culvert, the open-channel controls, and upstream- and downstream-released crayfish at the experimental culvert site (One-way ANOVA, $F=1.04, P=0.386$ ).

From the 179 PIT-tagged crayfish released (86 upstream and 93 downstream), 43 (24\%) were detected at least once within the culvert. No tagged crayfish were detected either side of the culvert within the exclusion zone, indicating that exclusion was effective. Thirty six (84\%) of all PIT-tagged crayfish detected in the culvert were ones released downstream and which had moved upstream (Figure 7). No significant relationships between location (metres along the culvert) and elapsed time were recorded for either group (Figure 7, regressions $P>0.05$ ), suggesting that there was continuous flux in entry and exit to the culvert. A small proportion of PIT-tagged crayfish were detected moving downstream $(7,7.5 \%$ of those released upstream) into the culvert, compared to $60 \%$ of radio-tagged crayfish released upstream, while 

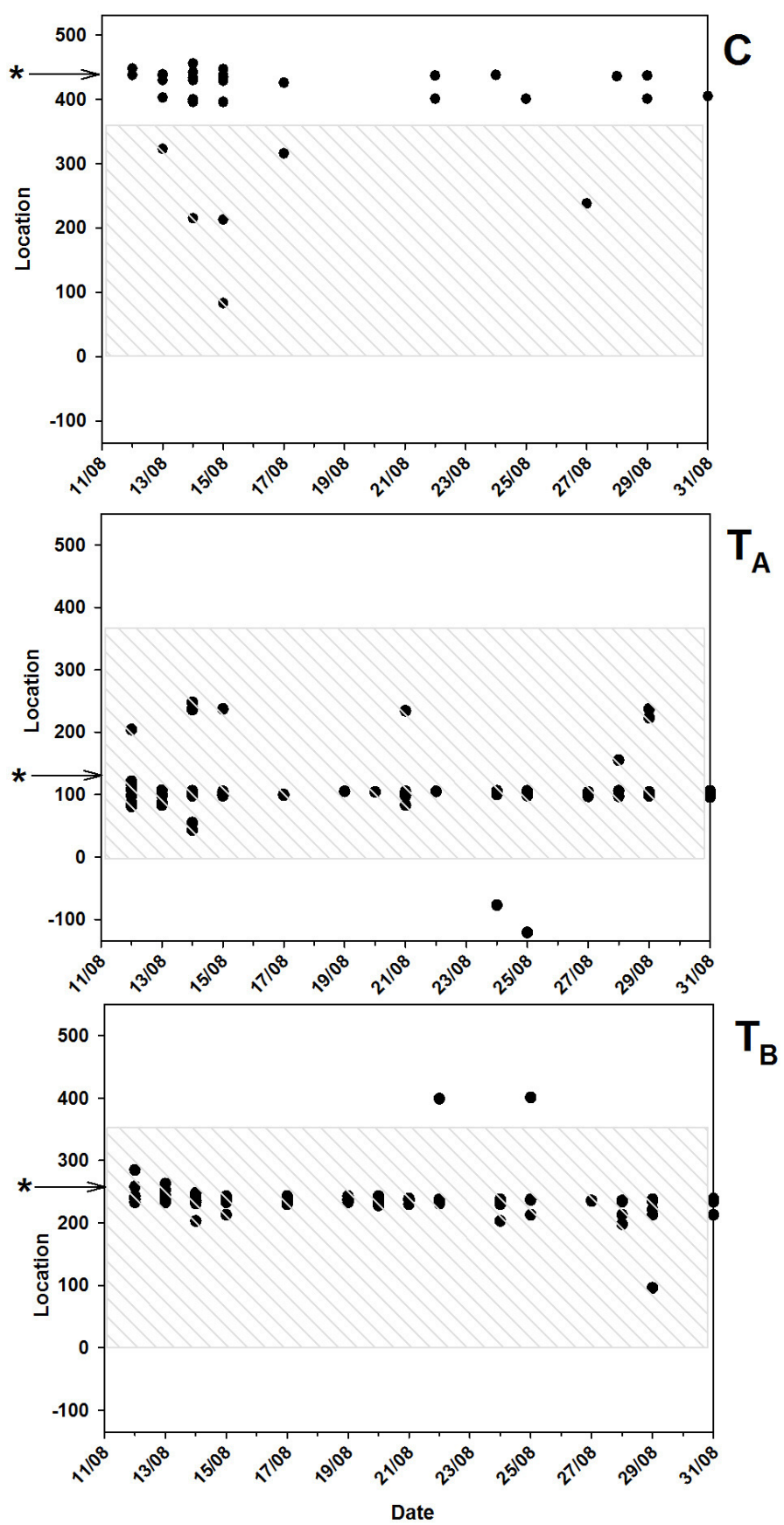

\section{Figure 4}

Distribution of PIT-tagged crayfish detected in Cotting Burn over the study period. * denotes the release position. Location on Y-axis, refers to the same locations indicated on Figures 1 and 2 Note that some points represent multiple detections of the same individual crayfish. The hatched regions indicate the extent of the covered culvert.

proportions of PIT- and radio-tagged crayfish released downstream detected in the culvert were more equitable, $41.9 \%$ and $70 \%$, respectively.

No significant difference in body size (CL) for crayfish detected in the culvert compared to those detected outside was observed for either radio or PIT-tagged crayfish; (Radio tags: for upstream and downstream combined: One way ANOVA, $F=0.13, P=0.718$ ); (PIT tags: Downstream released: One-way ANOVA: $F=0.76, P=0.385$; Upstream released: One-way ANOVA: $F=1.15, P=0.287$ ). 


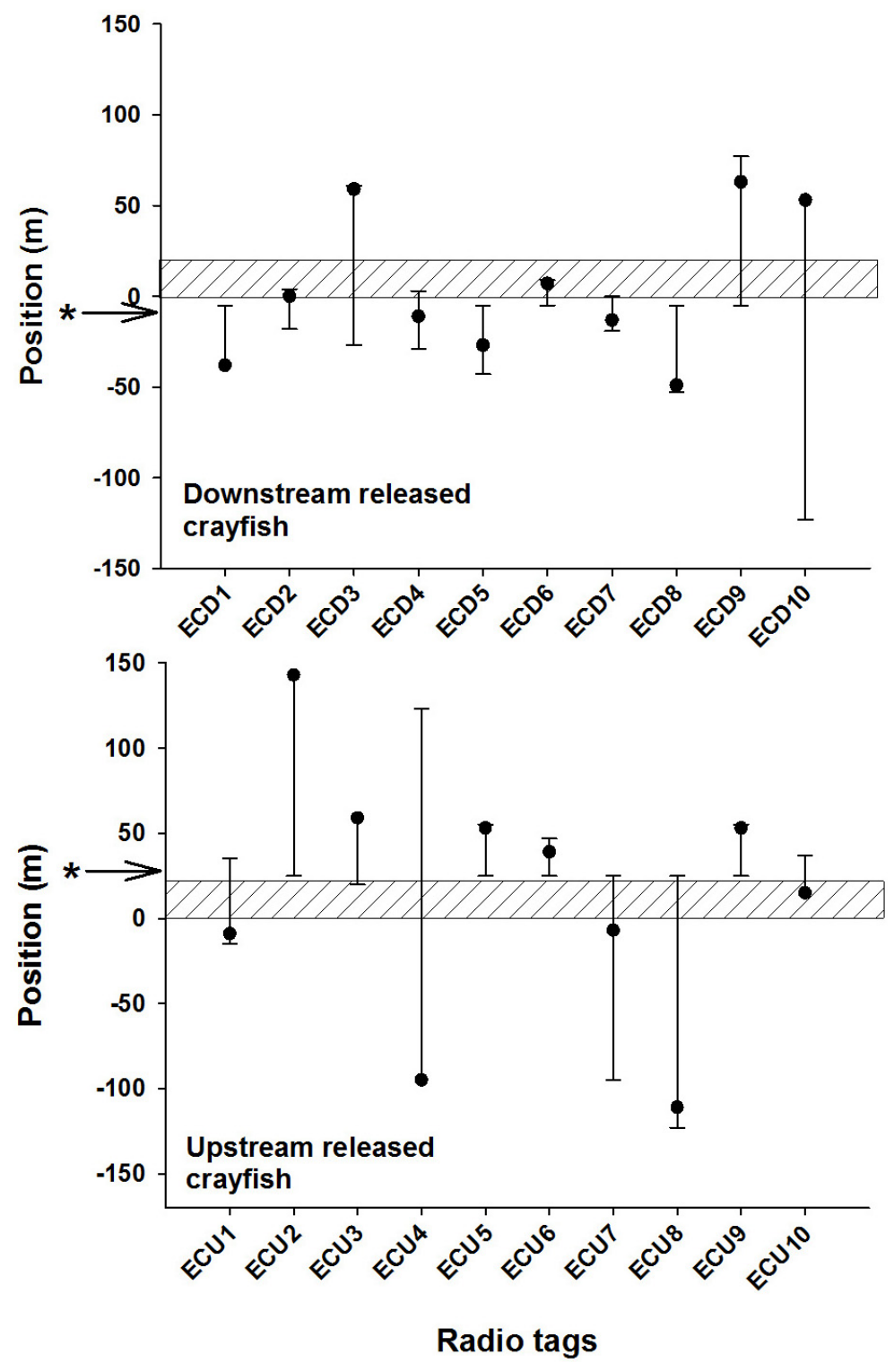

\section{Figure 5}

Locations of released radio-tagged crayfish (denoted by arrow and *) at the experimental culvert position (hatched box) on the River Wansbeck and the extent of the maximum distance moved during the experimental period (bars). The final position is depicted as a black dot.

\section{DISCUSSION}

This is the first study to determine the impact of dark, covered culverts on the movement of white-clawed crayfish; an endangered species severely affected by habitat fragmentation and loss amongst other factors (Holdich and Rogers, 1997; Peay and Füreder, 2011). The findings indicate that the continuously dark conditions created by culverts do not appear to alter the behaviour and consequently do not hinder the movement of adult white-clawed crayfish through them. Although multiple reports exist of white-clawed crayfish occurring and apparently living in dark culverts (T. Mercer, S. Peay, pers. comm.), including Cotting Burn (Latham, unpubl. data) those do not constitute evidence that such permanently dark structures do not limit dispersal potential. Nevertheless, the results are in many ways unsurprising as most crayfish species, including white-clawed crayfish, are strongly nocturnal and their sensory systems are well-adapted to activity in dark environments, relying heavily on tactile 


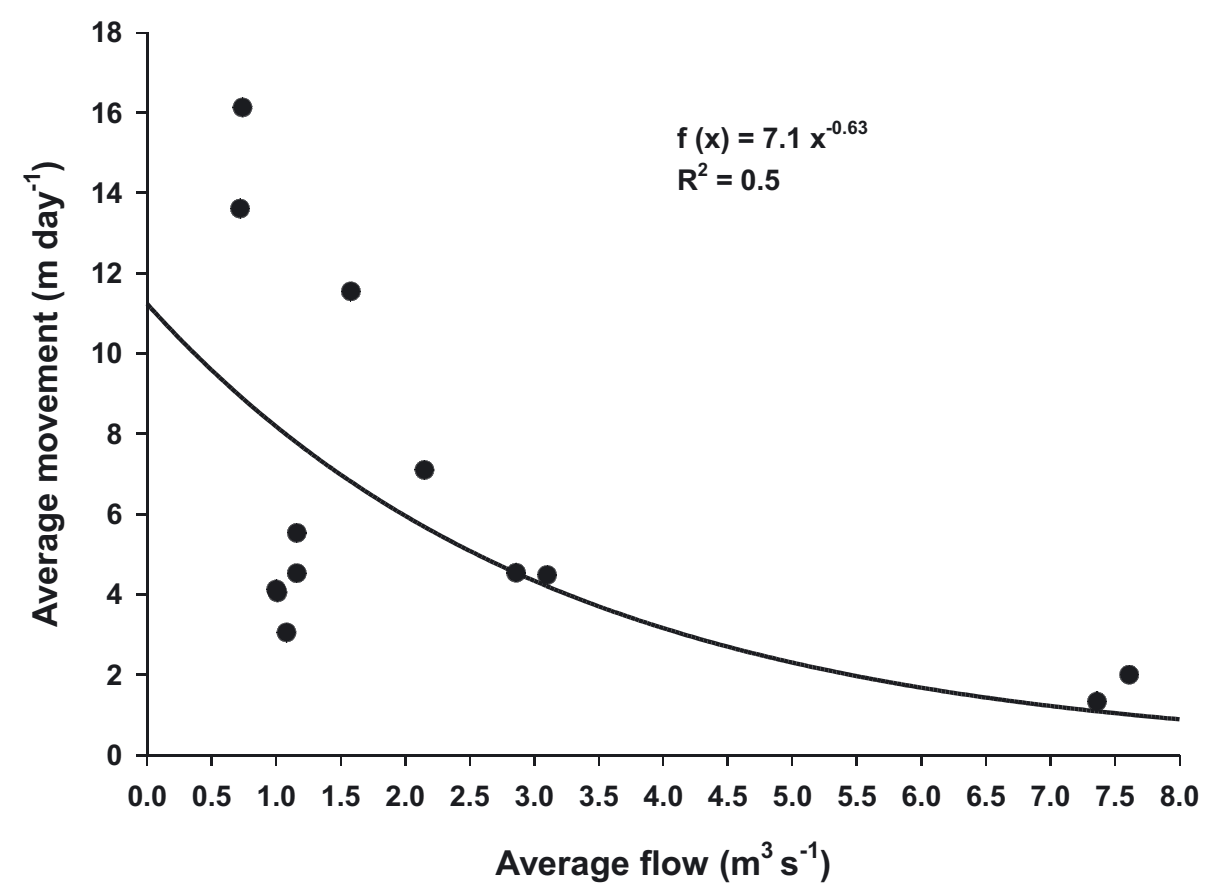

Figure 6

Relationship between average daily river flow of the Wansbeck at Mitford and average daily movement of radio-tagged crayfish.

\section{Table II}

Mean and standard error of daily rates of movement by radio-tagged crayfish from the Wansbeck (experimental culvert) and Cotting Burn (within vs. outside the covered culvert) study sites.

\begin{tabular}{|c|c|c|c|}
\hline Group & $N$ & $\begin{array}{l}\text { Mean daily distance } \\
\text { moved }\left(\mathrm{m}^{-1 a y}{ }^{-1}\right)\end{array}$ & $\begin{array}{l}\text { Standard } \\
\text { error }\end{array}$ \\
\hline Wansbeck - Released upstream of culvert & 10 & 6.4 & 1.95 \\
\hline Wansbeck - Released downstream of culvert & 10 & 7.3 & 1.74 \\
\hline $\begin{array}{l}\text { Cotting Burn - Released outside covered culvert } \\
\text { (Control) }\end{array}$ & 10 & 10.6 & 3.09 \\
\hline $\begin{array}{l}\text { Cotting Burn - Released within covered culvert } \\
\text { (Treatment) }\end{array}$ & 10 & 10.7 & 2.48 \\
\hline
\end{tabular}

and chemo senses, but with compound eyes well-adapted to dim light (Holdich and Crandall, 2002).

Both the existing and the constructed culvert used in the study achieved similar in situ light levels by day that are closely comparable to those of night-time levels $(0.1-1$ lux $=$ moonlit night, Schlyter, 2009; close to the sensitivity limit of most commercially available handheld light meters). In both cases, similar patterns of crayfish behaviour were observed, with crayfish entering culverts in upstream and downstream directions with no apparent inhibition.

No difference in rates of movement or pattern of spatial behaviour occurred between crayfish placed within dark culverts and those within control openchannel reaches. Nor was there any significant difference in rates of movement between radio-tagged crayfish in open or covered environments in Cotting Burn compared to those in the Wansbeck (Table II). The rates of movement, variation in individual rates, and patterns of spatial behaviour closely match those recorded elsewhere in streams and rivers for white-clawed crayfish during summer (Gherardi et al., 1998; Robinson et al., 2000; Bubb et al., 2006, 2008). Due to limitations in terms of the size of crayfish that could be tagged, this study considered only the response of adult individuals (which are typically mature at CL > 25 mm; (Brewis and Bowler, 1985) to darkened culverts. It is probable that juvenile crayfish will show similar responses to darkness 


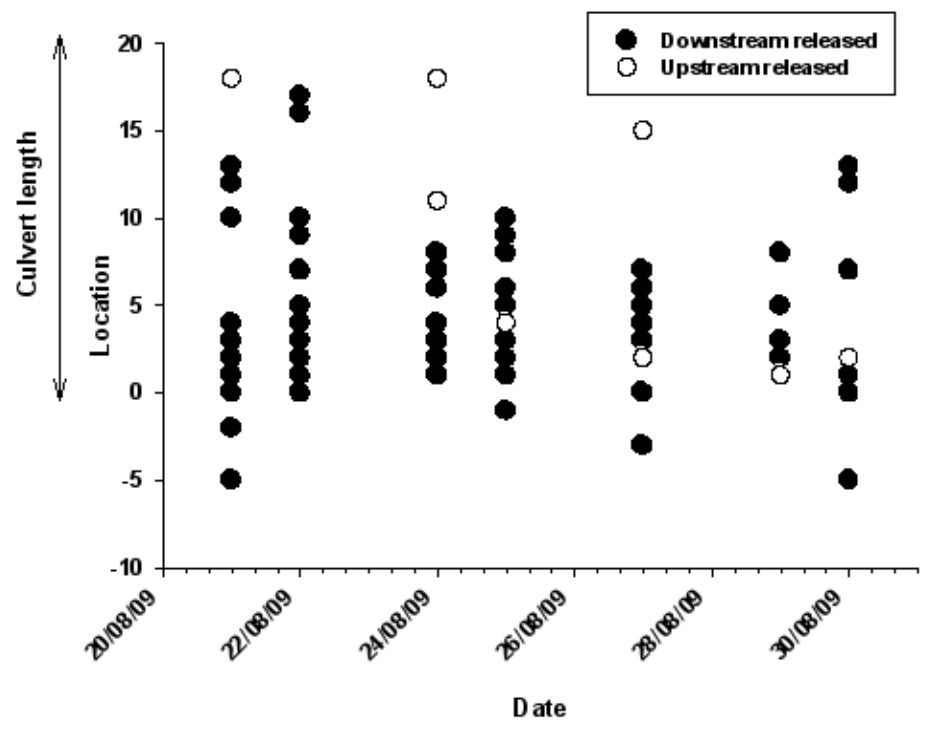

Figure 7

Detections of PIT-tagged crayfish in the experimental culvert, River Wansbeck. Note that some points represent multiple detections of the same individual crayfish.

as they have similar sensory physiology and predation pressures. However, juveniles do have reduced locomotor capability and, as in natural watercourses, would tend to be more capable of passing downstream, actively or passively, through such structures than upstream (Bubb et al., 2006).

This study observed limited movement upstream from release sites in concrete box culverts and past small obstructions, indicated by the high frequency of crayfish detected immediately downstream of the release site and potential barriers. However, multiple radio-tagged and PIT-tagged crayfish did move upstream through potential velocity barriers and in several cases past small physical obstructions. Bubb et al. (2006) showed that vertical structures as small as $0.2 \mathrm{~m}$ high can completely prevent upstream dispersal of white-clawed crayfish in streams, so the upstream movements past structures in the current study probably reflect the existence of micro-scale routes of sufficiently low gradient and velocity and adequate roughness for successful upstream passage. Visual observation showed that crayfish struggled to gain purchase on the smooth bed of sections of concrete box culvert and made upstream progress only at the water edges. It should be noted that the provision of pantiles as additional cover, almost certainly aided movement of crayfish through the box culverts, by potentially minimising predation, as well as by providing further low-flow micro-scale routes.

Recovery of several radio tags and PIT tags from multiple storm drains along the culvert's length, all raised above water level and all associated with crayfish fragments, vegetable matter and rat faeces strongly suggests they were predated by brown rat Rattus norvegicus (Berkenhout, 1769). It is conceivable that crayfish could have left the water, climbed the sloping edges, entered the storm drains and died or been eaten there. But since crayfish movement over smooth sloping concrete surfaces was observed to be difficult, this is improbable. Unlike some crayfish species, white-clawed crayfish rarely leave watercourses (Robinson et al., 2000; Bubb et al., 2008). The occurrence of eaten crayfish remains, but no whole ones, alongside the tags, together with gnawed and macerated vegetable material and rat faeces makes it highly likely that the crayfish were actively predated from the edges of the watercourse in the culvert and taken to the storm drain entrances to be eaten.

Few PIT-tagged crayfish were detected moving downstream through the experimental culvert on the Wansbeck, compared to the number detected moving upstream. Recapture of several PIT-tagged crayfish released upstream, but captured downstream at the end of the experiment, indicates that some PIT-tagged crayfish did move through in a downstream direction. As the radio-tracking results did not indicate any tendency for adult crayfish to 
preferentially move upstream, the low rate of detection of downstream-moving PIT-tagged crayfish might have been due to downstream-moving crayfish being able to move more easily and hence cover more ground than upstream-moving crayfish between scanning sessions, and so being less likely to be present within the culvert during a tag scanning session. It is also notable that despite strong water velocities in the experimental culvert (up to $0.61 \mathrm{~m} \cdot \mathrm{s}^{-1}$ ) PIT-tagged and radio-tagged crayfish moved up the culvert and a proportion of these passed right through the culvert. This flow velocity is twice the level recorded as having a noticeable impact on the ability of some native North American species of crayfish to move upstream (Foster and Keller, 2011). This might reflect the increased ability of white-clawed crayfish to move upstream compared to other species, but more likely, it highlights the importance of the presence of suitable river bed structure. The complex bed environment probably provides sufficient local low-flow routes and physical purchase for the walking legs, to enable upstream movement.

Although this study has demonstrated that dark culverts do not inhibit adult white-clawed crayfish spatial behaviour in any obvious way, this is under the assumption that changes in light conditions are the only habitat alteration caused by the culvert. Likely alterations in substrate habitat adjacent and in the culvert, presence of vertical barriers within the culvert (Bubb et al., 2008; Frings et al., 2013), as well as potential degradation of water quality (Mazza et al., 2011; Peay and Füreder, 2011), certainly have the capacity to influence entrance to and movement through a culvert by crayfish. So too does predation vulnerability; in the current study it appears that a lack of bed complexity in box concrete box culverts exposed crayfish to rat predation. Culverts, especially where natural habitat is sparse, may be expected to increase the susceptibility of crayfish to opportunistic predators, either in the culvert or at its extremities.

Because open and closed culverts are an extremely common form of infrastructure development, care needs to be taken about their installation, gradient and structure both for newbuilds and in maintenance and upgrading of older structures in relation to conservation of white-clawed crayfish and other mobile aquatic biota. The most common purpose of culverts is for water flow diversion and flood management. Many of the current concerns from fisheries and wildlife service departments revolve around ensuring that water velocities are passable for fish moving upstream, but where possible full stream-width culverts are being recommended, retaining or mimicking natural bed structure (Haro et al., 2004). For benthic animals, including crayfish, such conditions appear important for movement and predator avoidance, so should be encouraged where possible. Smooth-bedded concrete box culverts and smooth or corrugated pipe culverts are unlikely to be suitable for crayfish, as they do not provide refuge habitat and if strong flows span the culvert they are likely to impair upstream movement. While for white-clawed crayfish, unlit, covered culverts several hundred metres long do not appear to impinge on natural movement, this may not be true for other biota, especially day-active fish species and determination of the need for lighting will depend on the animal community for which functional connectivity is required. Culverts with nature-like beds, either uncovered or covered, are not likely to affect the conservation status of whiteclawed crayfish populations provided that the gradient is not too steep, flow velocities are not too high and suitable refuges are available. Where culverts incorporating nature-like habitat elements are not possible, compromise conditions of roughened beds, baffles to introduce flow variability (e.g. Franklin and Bartels, 2012) and refuge areas (e.g. cellular materials or masonry with cavities) may be appropriate but their suitability for crayfish movement and survival, as well as for a wider variety of biota requires better evaluation.

\section{ACKNOWLEDGEMENTS}

This work was funded by the Environment Agency. We are grateful to Philip Welton and Jim Heslop for discussions and facilitating work on the sites, and to Mitford Estate and Mrs Trimmings for access to the River Wansbeck where the experimental culvert was constructed. 


\section{REFERENCES}

Acosta C.A. and Perry S.A., 2001. Impact of hydropattern disturbance on crayfish population dynamics in the seasonal wetlands of Everglades National Park, USA. Aquat. Conserv., 11, 45-57.

Adams W.M. and Hughes F.M.R., 1986. The environmental effects of dam construction in tropical Africa: impacts and planning procedures. Geoforum, 17, 403-410.

Alberstadt P.J., Steele C.W. and Skinner C., 1995. Cover-seeking behavior in juvenile and adult crayfish, Orconectes rusticus: effects of darkness and thigmotactic cues. J. Crustacean Biol., 537-541.

Benstead J.P., March J.G., Pringle C.M. and Scatena F.N., 1999. Effects of a low-head dam and water abstraction on migratory tropical stream biota. Ecol. Appl., 9, 656-668.

Blakely T.J., Harding J.S., Mclntosh A.R. and Winterbourn MJ., 2006. Barriers to the recovery of aquatic insect communities in urban streams. Freshwater Biol., 51, 1634-1645.

Bojsen B.H., Witthøft H., Styrishave B. and Andersen O., 1998. In situ studies on heart rate and locomotor activity in the freshwater crayfish, Astacus astacus (L.) in relation to natural fluctuations in temperature and light intensity. Freshwater Biol., 39, 455-465.

Brewis J.M. and Bowler K., 1985. A study of reproductive females of the fresh-water crayfish Austropotamobius pallipes. Hydrobiologia, 121, 145-149.

Bubb D.H., Lucas M.C., Thom T.J. and Rycroft P., 2002. The potential use of PIT telemetry for identifying and tracking crayfish in their natural environment. Hydrobiologia, 483, 225-230.

Bubb D.H., Thom T.J. and Lucas M.C., 2006. Movement, dispersal and refuge use of co-occurring introduced and native crayfish. Freshwater Biol., 51, 1359-1368.

Bubb D.H, Thom T.J. and Lucas M.C., 2008. Spatial ecology of the white-clawed crayfish in an upland stream and implications for the conservation of this endangered species. Aquat. Conserv., 18, 647-657.

Dana E.D., García-de-Lomas J., González R. and Ortega F., 2011. Effectiveness of dam construction to contain the invasive crayfish Procambarus clarkii in a Mediterranean mountain stream. Ecol. Eng., 37, 1607-1613.

Dynesius M. and Nilsson C., 1994. Fragmentation and flow regulation of river systems in the northern third of the world. Science, 266, 753-762.

Fanjul-Moles M.L. and Prieto-Sagredo J., 2003. The circadian system of crayfish: a developmental approach. Microsc. Res. Tech., 60, 291-301.

Fanjul-Moles M.L., Escamilla-Chimal E.G., Gloria-Soria A. and Hernández-Herrera G., 2004. The crayfish Procambarus clarkii CRY shows daily and circadian variation. J. Exp. Biol., 207, 1453-1460.

Fernandez-De-Miguel F. and Arechika H., 1992 . Sensory inputs mediating two opposite behavioural responses to light in the crayfish Procambarus clarkii. J. Exp. Biol., 164, 153-169.

Foster H.R. and Keller T.A., 2011. Flow in culverts as a potential mechanism of stream fragmentation for native and nonindigenous crayfish species. J. N. Am. Benthol. Soc., 30, 1129-1137.

Franklin P.A. and Bartels B., 2012. Restoring connectivity for migratory native fish in a New Zealand stream: effectiveness of retrofitting a pipe culvert. Aquat. Conserv., 22, 489-497.

Frings R.M., Vaeßen S.C.K., Groß H., Roger S., Schüttrumpf H. and Hollert H., 2013. A fish-passable barrier to stop the invasion of non-indigenous crayfish. Biol. Conserv., 159, 521-529.

Gherardi F., Barbaresi S. and Villanelli F., 1998. Movement patterns of the white-clawed crayfish, Austropotamobius pallipes, in a Tuscan stream. J. Freshwater Ecol., 13, 413-424.

Gil-Sánchez J.M. and Alba-Tercedor J., 2006. The decline of the endangered populations of the native freshwater crayfish (Austropotamobius pallipes) in southern Spain: is it possible to avoid extinction? Hydrobiologia, 559, 113-122.

Haro A., Castro-Santos T., Noreika J. and Odeh M., 2004. Swimming performance of upstream migrant fishes in open-channel flow: a new approach for predicting passage through velocity barriers. Can. J. Fish. Aquat. Sci., 61, 1590-1601.

Holdich D. and Rogers W., 1997. The white-clawed crayfish, Austropotamobius pallipes, in Great Britain and Ireland with particular reference to its conservation in Great Britain. B. Fr. Pêche Piscic., 597-616.

Holdich D.M. and Crandall K., 2002. Biology of freshwater crayfish. Blackwell Science, Oxford, 702 p. 
Holdich D.M., Reynolds J.D., Souty-Grosset C. and Sibley P.J., 2009. A review of the ever increasing threat to European crayfish from nonindigenous crayfish species. Knowl. Managt. Aquatic Ecosyst., 11, 394-395.

IUCN 2013. The IUCN Red List of Threatened Species. Version 2013.2. http://www.iucnredlist.org. Downloaded on 21 November 2013.

Jegla T.C. and Poulson T.L., 1968. Evidence of circadian rhythms in a cave crayfish. J. Exp. Zoo., 168, 273-282.

Jones S.N. and Bergey E.A., 2007. Habitat segregation in stream crayfishes: implications for conservation. J. N. Am. Benthol. Soc., 26, 134-144.

Katopodis C., 2005. Developing a toolkit for fish passage, ecological flow management and fish habitat works. J. Hydraul. Res., 43, 451-467.

Kemp P. and Williams J., 2009. Illumination influences the ability of migrating juvenile salmonids to pass a submerged experimental weir. Ecol. Freshw. Fish, 18, 297-304.

Kerby J.L., Riley S.P.D., Kats L.B. and Wilson P., 2005. Barriers and flow as limiting factors in the spread of an invasive crayfish Procambarus clarkii in southern California streams. Biol. Conserv., 126, 402-409.

Larinier M., 2002. Biological factors to be taken into account in the design of fishways, the concept of obstructions to upstream migration. B. Fr. Pêche Piscic., 364, 119-134.

Light T., 2003. Success and failure in a lotic crayfish invasion: the roles of hydrologic variability and habitat alteration. Freshwater Biol., 48, 1886-1897.

Maceda-Veiga A., De Sostoa A. and Sánchez-Espada S., 2013. Factors affecting the establishment of the invasive crayfish Procambarus clarkii (Crustacea, Decapoda) in the Mediterranean rivers of the northeastern Iberian Peninsula. Hydrobiologia, 703, 33-45.

Mazza G., Agostini N., Aquiloni L., Carano G., Inghilesi A.F., Tricarico E. and Gherardi F., 2011. The indigenous crayfish Austropotamobius pallipes complex in a national park of Central Italy. Knowl. Managt. Aquatic Ecosyst., 401, 24.

Pearson C.E., 2011. Spatial patterns of habitat use by white-clawed crayfish (Austropotamobius pallipes) on the River Wansbeck. MSc (Res.) thesis, Durham University, 168 p.

Peay S. and Füreder L., 2011. Two indigenous European crayfish under threat-how can we retain them in aquatic ecosystems for the future? Knowl. Managt. Aquatic Ecosyst., 401, 33.

Ream H.M., 2010. Microhabitat use and recolonisation in white-clawed crayfish: application to conservation. MSc (Res.) thesis, Durham University.

Richter B.D., Braun D.P., Mendelson M.A. and Master L.L., 1997. Threats to imperiled freshwater fauna. Conservation Biol., 11, 1081-1093.

Robinson CA., Thom T.J. and Lucas M.C., 2000. Ranging behaviour of a large freshwater invertebrate, the white-clawed crayfish Austropotamobius pallipes. Freshwater Biol., 44, 509-521.

Schlyter P., 2009. Radiometry and photometry in astonomy. Available at: http://stjarnhimlen.se/comp/ radfaq.html\#10.

Souty-Grosset C. and Reynolds J., 2009. Current ideas on methodological approaches in European crayfish conservation and restocking procedures. Knowl. Managt. Aquatic Ecosyst., 01, 394-395.

Tonkin J.D., Wright L.A.H. and David B.O., 2012. Mussel spat ropes assist redfin bully Gobiomorphus huttoni passage through experimental culverts with velocity barriers. Water, 4, 683-689. 